EXEMPLARIa Classica

Journal of Classical Philology

21, 2017, pp. 73-80

ISSN 1699-3225

\title{
THE DEFINITION OF LEXEMES ACCORDING TO THE DICCIONARIO GRIEGO-ESPAÑOL DEL NUEVO TESTAMENTO (DGENT) ${ }^{1}$
}

\author{
DÁMARIS ROMERO \\ Universidad de Córdoba \\ ca2rogod@uco.es
}

\section{SUMMARY}

The aim of this article is to show three types of definitions used in the Diccionario Griego-Español del Nuevo Testamento $(D G E N T)$ to define certain grammatical categories. Each type of definition will be explained and illustrated with examples taken from the Diccionario.

\section{KEY WORDS}

Definition; Diccionario Griego-Español del Nuevo Testamento; lexicographical definition; explanatory definition; encyclopaedic definition.

\section{RESUMEN}

El propósito de este artículo es mostrar los tres tipos de definición que se emplean en el Diccionario Griego-Español del Nuevo Testamento (DGENT) para definir las categorías gramaticales. Junto a la explicación de cada tipo de definición, se añadirán unos ejemplos tomados del Diccionario.

Palabras Clave

Definición; Diccionario Griego-Español del Nuevo Testamento; definición lexicográfica; definición explanatoria; definición enciclopédica.

Fecha de recepción: 11/04/2016

Fecha de aceptación y versión final: 15/01/2017

${ }^{1}$ This article has been prepared within the framework of the Diccionario Griego-Español del Nuevo Testamento Research Programme financed by the Spanish Ministry for Science and Innovation. General Directive for Programs and Knowledge Transfer 2011-2014 (FFI201126124). I would like to thank Artur Kocialkowski for checking my English. The remaining mistakes are mine. Also I would like to thank the anonymous referees for their suggestions, which have improved the article. 
In the preface of his Essays on Definition, J.C. Sager explains the important role of defining and definition in Lexicography as "they are the conventional means for establishing the meaning of lexical items, or, expressed differently, for connecting the concept with the word or term that represents it".

Although it seems simple and plain -it is just to develop the concept that underlies a lexeme-, there is not a single way to explain the concept, as there is not an only one type of word. In consequence, it is necessary to define a word according to its grammatical category -or related grammatical categories. As a result, one type of definition would be used to define the adjective and another for defining the preposition.

This motto is followed in the elaboration of the definition of lexemes in the Greek-Spanish New Testament Dictionary (DGENT). Thus, this article aims to show the diverse types of definitions and the different defining structures applied to define the grammatical categories in the DGENT.

\section{The DEFINITION IN THE DGENT}

Before showing the different types of definition we employ in the DGENT, it is necessary to distinguish between meaning and translation, being it the principal premise of our dictionary. The translation of a word means transferring it from a source language into another in a target language taking into account the context of the word, whereas the meaning of a word is "the information that a word contains and transmits isolated or in context". ${ }^{3}$ To say it in another way, the meaning is not just expressed solely by a word, but by a sentence which describes its content, a metalinguistic description which we consider as the definition: "a paraphrase (or expansion) which demonstrates the set of semantic features contained in the lexeme, according to the order corresponding to the configuration of its components". 4

Now that both concepts have been distinguished, meaning and translation, we will deal with the topic of the article, the types of definitions and their structures depending on the grammatical category of the defined word. Taking it into account, a first model of definition will be given for nouns, adjectives and verbs (lexicographical definition); a second one will be for

${ }^{2}$ Cf. J. C. Sager, Essays on Definition, Amsterdam - Philadelphia 2000, 1.

${ }^{3}$ Cf. J. Peláez, "Significado / traducción y definición de las palabras en el Diccionario Griego-Español del Nuevo Testamento (DGENT)”, in M. Alganza Roldán, coord., Epieikeia. Studia graeca in memoriam de Jesús Lens Tuero, Granada 2000, 391.

${ }^{4}$ Cf. J. Peláez, "La definición de los lexemas en el Diccionario Griego-Español del Nuevo Testamento (DGENT): Basileía y lexemas afines”, in M. Valverde Sánchez - E. A. Calderón Dorda - A. Morales Ortiz, coords., Koinòs lógos: Homenaje al profesor José García López II, Murcia 2006, 757; F. Lautaro Roig Lanzillotta, "The Greek-Spanish Dictionary of the New Testament (DGENT): Meaning and Translation of the Lexemes; Some Practical Examples", in R. A. Taylor - C. WE. Morrison, Reflections on Lexicography. Explorations in Ancient Syriac, Hebrew, and Greek Sources, New Jersey, USA, 2013, 281. 
prepositions, conjunctions and interjections (explanatory definition), and, finally, a third one will be for certain names, realia and proper names (encyclopaedic definition) ${ }^{5}$

\subsection{DeFINING NOUNS, ADJECTIVES \& VERBS: LEXICOGRAPHICAL DEFINITION}

The first type of definition, used in the DGENT for the definition of nouns, adjectives and verbs, is the lexicographical one, also known as analytical definition. Its objective is to specify the meaning of the word, and it will be achieved by "[enumerating] only the most important semantic features ... which suffice to differentiate it (scil. the defined word) from other units". 6 Accordingly, we consider these semantic features are the denoted semantic categories and the majority of the connoted ones of the word.

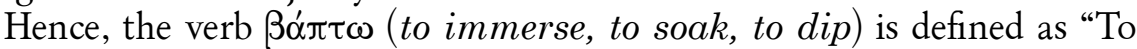
place somebody or something in water or another liquid", definition which contains the denoted semantic categories (the action and the location of this action -a liquid material-) and the connoted ones (the subject and the term).

The same applies to the noun $\beta \alpha \pi \tau \imath \sigma \mu o$ s (washing, rising; ablution); its definition is created considering the denoted and most of the connoted semantic categories: "The action of placing (denoted) somebody or something (connoted) in water to purify (denoted) it". In this case, the connoted subject is supressed because it is an abstract noun.

But, would it be possible to know if the lexicographical definition is correct or properly formed? The answer is affirmative. We know that the definition of a noun, an adjective or a verb is acceptable when the 'synonymic test' is passed: The definition should be considered a substitute or a synonym of the word and it should be placed in the sentence instead of the defined word without important changes in the meaning of the sentence.

Of course, we understand that the perfect synonymy does not exist and only on rare occasions it is absolute, so that "the sameness of meaning between the defined word and the definition is just an approximation, an equivalence 'for practical purposes".?

Once more, we will exemplify this 'synonymic test' with the verb ßó $\pi \tau \omega$, whose definition is "To place somebody or something in water or another

\footnotetext{
${ }^{5}$ We are aware of the various types of definitions, "such as the morphological definition (a formulation unwrapping a derivative word, e.g. swiftly in a swift fashion), extensional definition (enumerating typical exemplars, e.g. legume a seed such as a pea or bean), or ostensive definition (pointing to the definiendum)", cf. R. Lew, "Identifying, Ordering and Defining Senses", in H. Jackson, ed., The Bloomsbury Companion to Lexicography, London 2013, 298, but we will only explain and show the definitions which appear in the DGNT.

${ }^{6} \mathrm{Cf}$. C. Ostermann, Cognitive Lexicography. A New Approach to Lexicography Making Use of Cognitive Semantic, Berlin 2015, 29-30.

${ }^{7}$ M. Seco, Estudios de Lexicografía española, Madrid 2003, 32. The translation is mine.
} 


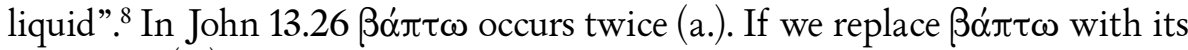
definition (b.), the verse still makes sense:

a. "It is he to whom I shall give a piece of bread when I have dipped it". And having dipped the bread...

b. "It is he to whom I shall give a piece of bread when I have placed it into water". And having placed the bread into water...

The same possibility of substitutability occurs with the noun $\beta \alpha \pi \tau 1 \sigma \mu$ ó $^{.}{ }^{9}$ In Mark 7.4 this noun appears related to the washing of cups (c.) and it is possible to change this word with its definition without losing sense of the verse (d.):

c. "And they observe many others traditions, such as the washing of cups, pitchers and kettles".

d. "And they observe many others traditions, such as the action of placing cups, pitchers and kettles into water to purify them".

As an immediate consequence of this similarity, which could also be considered a second requirement of a well-constructed definition, is the identification of the grammatical category of the defined word and the definition. In other words, the definition should begin with the same grammatical category as the word itself. Thus, if the word is a noun, the definition should start with a noun followed by complements, or a nominal construction; if the word is an adjective, the definition should begin with an adjectival subordinate sentence; and, finally, if the word is a verb, the definition should start with a verb in the infinitive. ${ }^{10}$

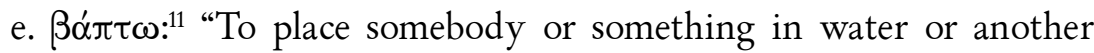
liquid".

${ }^{8}$ Another example is Lk 16.24 .

${ }^{9}$ Other examples are Heb 6.2; 9.10.

${ }^{10}$ The same pattern occurs if the word is an adverb: it should begin with an adverbial phrase, but because this root does not form an adverb, so this grammatical category will not be exemplified.

${ }^{11}$ The cognate verb, $\beta \alpha \pi \tau i \xi \omega$, denotes an action located in a liquid material and connotes a subject and two terms, because it adds to the meaning the aim of the action. So, its definition is "To place (the action) somebody or something (the connoted term) in (the location) water (the material) to purify (the connoted aim) it" and its translations are to dip, to soak, to wash. As it can be observed, the framework for the definition of $\beta \alpha \pi \tau i \zeta \omega$ is quite similar to $\beta \alpha \dot{\alpha} \tau \tau \omega$; it has just added the new connoted semantic category, the relation of purpose. In Luke 11.38, the author writes: "the Pharisee marvelled that He had not first washed before dinner". Again, the verse is not meaningless if $\left.\beta \alpha \pi \tau^{\prime}\right\} \omega \omega$ is substituted by its definition: "the Pharisee marvelled that He had not first placed [himself or his hands] in water to purify him before dinner". 
f. $\beta \alpha \pi \tau$ « $\sigma$ ós: "The action of placing somebody or something in water to purify it".

However, what happens if a word has more meanings? The requirements are the same,${ }^{12}$ and even a new third one could be added: the definition of these new meanings should maintain the "literary expression" of the definition of the lexical meaning, as much as possible, with the added semantic categories, so that it is possible to observe the relation between both meanings. Thus, $\beta \alpha \pi \tau i\} \omega$ has a second sense, and probably the best known in the New Testament, when it is always referred to a person (contextual factor), which gives a symbolic meaning to this verb. Therefore, in this contextual meaning $\beta \alpha \pi \tau i \zeta \omega$ denotes an action, the manner in which it is performed (new added denotation) and the location in a liquid material, and it connotes a subject and two terms (the person who receives the benefit of the action and the aim of the action). Accordingly, the definition of this meaning of $\left.\beta \alpha \pi \tau^{\prime} i\right\} \omega$ is "to immerse or place somebody ritually in water as a sign of repentance".

Compared with its lexical meaning ("To place somebody or something in water to purify it"), it can be observed that the "literary expression" is similar, as it preserves the majority of this "literary expression". Furthermore, this definition mostly contains the semantic categories of the definition of the lexical meaning and adds the new ones (in italics): "To immerse or place (the action) somebody (the personal connoted term) ritually (the manner) in (the location) water (the material) as a sign of repentance (the aim)".

The "literary expression" or framework of the definition of this contextual meaning is also present in the other derived words, as $\beta \alpha \pi \tau i \sigma \tau \eta \dot{s}$ and

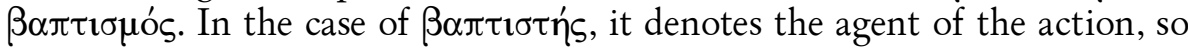
the subject is inserted in the definition as a denoted semantic category, instead of being outside, as a connoted one, as it is in the verb. Consequently, the definition is "A person who immerses somebody ritually in water as a sign of repentance".

Similarly, the same occurs in $\beta \alpha \pi \tau \imath \sigma \mu o ́ s:$ the framework continues, but the subject disappears, because it is an abstract noun. It is defined as "The action of immerging somebody ritually in water as a sign of repentance".

To make a brief summary, we consider an appropriate lexicographical definition when four requirements are fulfilled:

1. The definition contains each denoted semantic category and the majority of the connoted ones.

2. The definition can be considered a substitute or a synonym of the word.

12 We do not insist on the substitutability and the identification of the grammatical category between words, as we mean to emphasize the third requirement: the preservation of the definition's framework. 
3. The definition starts with the same grammatical category as the defined word.

4. The definition of the cognate words maintains the same "literary expression" or framework (although some elements could vary depending on the defined grammatical category).

\subsection{DEFINING PREPOSITIONS, CONJUNCTIONS AND INTERJECTIONS: EXPLANATORY} DEFINITIONS

However, not all the grammatical categories can be defined using this type of definition. Interjections, prepositions and conjunctions can only be explained but not defined, ${ }^{13}$ for the only information that the dictionary could provide for these words is how and for what purpose they are used, not what they mean. ${ }^{14}$ Because of this, the definition in question could be called 'explanatory'.

Although all these definitions also contain the denoted semantic categories and the majority of the connoted ones, they emphasize more the semantic use of the word than its semantic content. Thus, the main difference from the former type of definition is the impossibility to replace the defined word, and in consequence, the beginning of the definition cannot start with the same grammatical category. We will exemplify it with the first sememe of the preposition $\dot{\alpha} \pi 0^{15}$

In its first sememe, this preposition denotes location in relation to a subject and a term, both connoted, and it is started to be defined not with a preposition, but with a noun: "The mark of separation or distance from a reality over another": from.

In Matthew 8.1 it is said that "when Jesus had come down from the mountain, great multitudes followed Him". If $\dot{\alpha} \pi$ ó is replaced by the definition, the verse does not make sense: "when Jesus had come down mark of separation or distance from a reality over another the mountain, great multitudes followed Him".

Because this type of definition is focused on the use and not on the meaning of the word, the framework and the content of the definition are different from the lexicographical one and the synonymic substitutability cannot be applied.

\subsection{DEFINING PROPER NAMES: ENCYCLOPAEDIC DEFINITIONS}

A third type of definition is the one employed for proper names (people and places) and those that design plants, animals, objects or institutions

${ }^{13}$ Cf. I. Bosque, "Sobre la teoría de la definición lexicográfica", Verba 9, 1982, 106; Seco, Estudios, 33-4.

${ }^{14}$ Cf. Seco, Estudios, 33.

${ }^{15}$ Cf. J. Mateos - J. Peláez, eds., Diccionario Griego-Español del Nuevo Testamento (III, $\dot{\alpha} \nu \theta i ́ \sigma \tau \eta \mu 1-\dot{\alpha} \pi \omega \dot{\lambda} \lambda \varepsilon 1 \alpha)$, Córdoba 2007, 789-829. 
(realia). They do not need to be analysed semantically (they are entities mostly) and in these cases, the DGENT simply gives the translation ${ }^{16}$ or an encyclopaedic definition, in which the semantic aspects of the word are not explained but rather the descriptive ones, those "whose referents are part of the cultural background (history, geography, etc.)"17 or are characteristics of the 'defined' object, so that it is possible to say that this type of definition describes the lexeme itself. This type of definition could be considered as similar to the "full-sentence definition (FSD)", because both give an explanation of the word. The difference may be that the DGENT does not embed the defined word into the definition ${ }^{18}$.

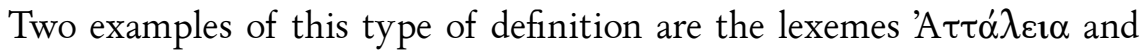

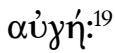

'A $\tau \tau \alpha \dot{\lambda} \varepsilon \varepsilon \alpha, \alpha \varsigma, \dot{\eta}(1)$, Attalia, port city from Pamphylia, in the south coast of Asia Minor, from where Paul and Barnabas sailed to Antioch, Acts 14.25.

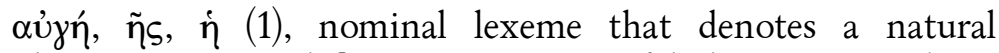
phenomenon. Its definition is "Beam of light given out by a light body" and its translations are brightness, shine.

The description itself explains the word "by providing factual information about the item". ${ }^{20}$ Because the description of these types of lexemes given in the DGENT is brief -just the basic information about the word-, they are collected in separate volumes, in which a more detailed explanation is offered. ${ }^{21}$

\section{ConcLusions}

We can sum up some conclusions. Firstly, every definition combines the denoted and the connoted semantic categories included in a lexeme. Although this general description applies to every word in the DGENT, every word cannot be described in the same manner. As H. Jackson refers,

${ }^{16}$ Cf. J. Mateos - J. Peláez, eds., Diccionario Griego-Español del Nuevo Testamento(IV, "A $\rho$ - ö $\psi v x o s)$, Córdoba 2010, VI.

${ }_{17}$ Cf. Bosque, "Teoría de la definición”, 112.

${ }^{18}$ Cf. Lew, "Identifying, Ordering and Defining Senses", 297.

${ }^{19}$ DGENT IV, 1145 and 1147.

${ }^{20}$ Cf. R. R. K. Hartmann- G. James, eds., Dictionary of Lexicography, London - New York 2002, 36.

${ }^{21}$ For example, in the Dictionary of Geographic Places of the New Testament (Diccionario geográfico del Nuevo Testamento) the entry for Dalmatia contains the location of the toponym, a note on its history and information about the place obtained from all the occurrences of it in the New Testament, cf. P. Godoy, Diccionario geográfico del Nuevo Testamento, s.u. Dalmacia (2010: 50) 
"different forms of definition are appropriate to different types of words". ${ }^{22}$ Hence, various type of definition will be used depending on the grammatical category of the word: lexicographical for nouns, adjectives, verbs and adverbs; explanatory for prepositions, conjunctions and interjections, and encyclopaedic for certain nouns (realia and proper names).

Secondly, to determine if a lexicographical definition is correct, it is necessary to consider three points:

1. It should start with the same grammatical category as the word which is being defined. E.g., if the word is a noun, the definition has to begin with a noun.

2. It can be considered a substitute or a synonym of the word.

3. The definition of the cognate words maintains the same "literary expression" or framework.

Because the explanatory and encyclopaedic definitions do not give the meaning of the word but rather its usage or factual information about it, these points cannot be applied to both types of definition.

Thus, to properly define a word is not an easy task, not only because many different aspects of format and content should be considered, but also because the definition is, without a doubt, either the key to understand a word or the very heart of itself. As Virginia Woolf wrote, "a word without a meaning is a dead word, a corrupt word". 23

${ }^{22}$ Cf. H. Jackson, ed., Lexicography: An Introduction, London - New York 2002, 94.

${ }^{23}$ V. Woolf, A Room of One's Own and Three Guineas, London 2014, 3. 